Cardiology 1970;55:I-VIII

\title{
Contents, Vol. 55, 1970
}

\section{Cardiology}

Succeeding Cardiologia. International Archives of Cardiology

Founded by Bruno Kisch and Wilhelm Löffler, continued by Robert Hegglin, Ernst Lüthy and Ivan Mahaim

Editor

P. M. Galletti, Providence, R.I.

Editorial Board

Domingo M. Aviado, Philadelphia, Pa.

Anthony N. Damato, Staten Island, N.Y.

Robert H. Franch, Atlanta, Ga,

J. O'Neal Humphries, Baltimore, Md.

John W. Mannig, Atlanta, Ga.

Robert H. McDonald, jr., Pittsburg, Pa.

Pierre R. Moret, Geneve

Albert S. Most, Providence, R.I.

Bertram Pitt, Baltimore, Md.

Burton J. Polansky, Boston, Mass.

Frederic Reichel, Providence, R.I.

James Scheuer, Pittsburgh, Pa.

Collaborators

Viking Olov Björk, Stockholm

Ignacio Chavez, Mexico

Eduardo Coelho, Lisboa

P. W. Duchosal, Geneve

J. Gibert-Queraltó, Barcelona

Arthur Grollman, Dallas, Tex.

Juan A. Izquierdo, Buenos Aires

J. Lequime, Bruxelles

David Scherf, New York, N.Y.

A. Schott, Gerrards, Cross, Bucks.

áke Senning, Zurich

Paul D. White, Boston, Mass.

E. Wollheim, Würzburg

\section{SWK}

S. Karger · Basel · München · Paris · London · New York · Sydney

S. Karger · Basel · München · Paris · London · New York · Sydney Arnold-Böcklin-Strasse 25, CH-4000 Basel 11 (Switzerland) 
All rights, including that of translation into other languages, reserved. Photomechanic reproduction (photocopy, microcopy) of this volume or parts thereof without special permission of the publishers is prohibited.

(C) Copyright 1970 by S. Karger AG, Verlag für Medizin und Naturwissenschaften, Basel Printed in Switzerland by Buchdruckerei Friedrich Reinhardt AG, Basel

Contents

Agostoni, A.: see Stabilini, R.

Amorim, D. S.; Chambers, R. J.; Beck, W.; Somers, K.; Manço, J. C, and

Gallo, L., jr.: Comparative Observations of the Impairment of

Autonomic Responses in Chronic Chagas' Heart Disease and in

African Myocardiopathies 321

Areskog, N.-H.: see Sievers, J.

Aronow, W. S.; Cassidy, J., and Uyeyama, R. R.: The Resting and Post-

exercise Phonocardiogram and Electrocardiogram in Asymptomatic

Women 333

Bada, V.: see Gvozdják, J.

Beck, W.: see Amorym, D. S.

Blümchen, G.; Landry, F.; Kiefer, H., and Schlosser, V.: Hemodynamic

Responses of Claudicating Extremities. Evaluation of a Long Range

Exercise Program 114

Bocanová, M.: see Gvozdják, J.

Boréus, L. O.: see Hörnblad, P. Y.

Brinton, G.: see Burdick, J. A.

Burch, G. E. and Giles, T. D.: A Digital Rheoplethysmographic Study of the

Vasomotor Response to 'Simulated Diving' in Man 257

Burdick, J. A.; Brinton, G.; Goldstein, L., and Laszlo, M.: Heart-Rate

Variability in Sleep and Wakefulness 79

Cassidy, J.: see Aronow, W. S.

Chambers, R. J.: see Amorim, D. S.

Chandrasekhar, K. P.: see Vérel, D.

Chevalier-Cholat, Am.: see Torresani, J.

Chuck, L.: see Parmley, W. W.

Chung, E. K.: Some Thoughts Concerning the Nomenclature of A-V Nodal

Arrhythmias 156

Chung, E. K.: Use and Abuse of Direct Current Shock 310

Chung, E. K. and Dean, H. M.: A Recognition of Digitalis Intoxication in the

Presence of Atrial Fibrillation 22

Chung, E. K. and Jewson, D. V.: Ventriculophasic Sinus Arrhythmia in the

Presence of Artificial Pacemaker Induced Ventricular Rhythm .... 65

Coltart, D. J. and Meldrum, S. J.: A Comparison of the Transmembrane

Action Potential of the Human and Canine Myocardium 340

Dean, H. M.: see Chung, E. K.

Dhalla, N. S.; McNamara, D. B., and Sulakhe, P. V.: Excitation-Contraction Coupling in Heart.

V. Contribution of Mitochondria and Sarcoplasmic Reticulum in the Regulation of Calcium

Concentration in the Heart 178

Dighiero, J.: see Folle, L. E. 
VI

Contents

Dolara, A.; Manetti, A.; Pozzi, L., and Tordini, G.: Bidirectional Tachycardia 302

Elena, R.: see Folle, L. E.

Fiorelli, G.: see Stabilini, R.

Folle, L. E.; Dighiero, J.; Sadi, I.; Pommerenck, C, and Elena, R.: Hemo-

dynamic Response to Exercise after Beta-Adrenergic Blockade in

Normal and Labile Hypertensive Patients 105

Fondarai, J. A.: see Torresani, J.

Gallo, L., jr.: see Amorim, D. S.

Giles, T. D.: see Burch, G. E.

Goldstein, L.: see Burdick, J. A.

Gomez, F. P.: see Norris, A. D. C.

Groom, D.: Standardization in Phonocardiography: The Microphone Pickup 129

Gvozdják, J.; Bada, V.; Bocanová, M.; Kapeller, K., and Mráz, P.: Changes

of Myocardial Mitochondria in Experimental Cardiomyopathies ... 84

Heuillet, G.: see Torresani, J.

Hörnblad, P. Y.; Boréus, L. O., and Larsson, K. S.: Studies on Closure of the

Ductus arteriosus. VIII. Reduced Closure Rate in Guinea Pigs

Treated with Phenoxybenzamine 237

Jewson, D. V.: see Chung, E. K.

Jouve, A.: see Torresani, J.

Kapeller, K.: see Gvozdják, J.

Kee Soon Kim; Randall, W. C, and Peiss, C. N.: Cardiovascular Responses

to Hypothalamic, Spinal Cord and Stellate Ganglion Stimulation 164

Kiefer, H.: see Blümchen, G.

Kroetz, F. W.: see Scheuer, J.

Landry, F.: see Blümchen, G.

Larsson, K. S.: see Hörnblad, P. Y.

Laszlo, M.: see Burdick, J. A.

Leonard, J. J.: see Scheuer, J.

Levi, G. F. and Proto, C: Combined Treatment of Atrial Fibrillation with

Propranolol and Quinidine 249

Levine, H. D. and Smith, C, jr.: Repetitive Paroxysmal Tachycardia in Adults.

Prognosis - Relationship to Nervous System and to Classical Tachy

cardia 2

Lyntermans, J. P.; Ruiz-Ayuso, F., and Mullem, J. van: Multiple Aortic

Aneurysms in a 7-Year-Old Negro Child 351

Maddalena, F.: see Piccolo, E.

Magri, G.: see Pintor, Pinna P.

Manço, J. C: see Amorim, D. S.

Manetti, A.: see Dolara, A.

Marinari, M.: see Stabilini, R.

Matloff, J.: see Parmley, W. W.

McNamara, D. B.: see Dhalla, N. S.

Meldrum, S. J.: see Coltart, D. J. 
Mráz, P.: see Gvozdják, J.

Mullem, J. van: see Lintermans, J. P.

Nagaratnam, N.: Alcohol and Heart Disease in Ceylon

\section{Contents VII}

Nagaratnam, N. and Siripala, K. A.: Myocardial Toxoplasmosis in Ceylon 272

Nava, A.: see Piccolo, E.

Norris, A. D. C. and Gomez, F. P.: The Electrocardiogram in Coarctation of the Aorta 149

Olsson, B.; Pool, J.; Vandermoten, P.; Varnauskas, E., and Wassén, R.:

Validity and Reproducibility of Determination of Cardiac Output

by Thermodilution in Man 136

Onat, T.: Influence of the Respiratory Cycle on the Configuration of the

Heart and Vessels in the Chest X-Rays of Children 281

Pace, J. B.: Sympathetic Control of Right Ventricular Dynamics 218

Parmley, W. W.; Chuck, L., and Matloff, J.: Diminished Responsiveness of the Failing Human Myocardium to Glucagon

211

Peiss, C. N.: see Kee Soon Kim

Piccolo, E.; Nava, A.; Maddalena, F., and Pujatti, G.: Wandering Pace

maker - A Vectorcardiographic Study

Pintor, Pinna P. and Magri, G.: Digitalis and Mitral Surgery 34

Pommerenck, C: see Folle, L. E.

Pool, J.: see Olsson, B.

Pozzi, L.: see Dolara, A.

Proto, C: see Levi, G. F.

Pujatti, G.: see Piccolo, E.

Radice, F.: see Stabilyni, R.

Randall, W. C: see Kee Soon Kim

Ruiz-Ayuso, F.: see Lintermans, J. P.

Saadjian, A.: see Torresani, J.

Sadi, I.: see Folle, L. E.

Scheuer, J.; Shaver, J. A.; Kroetz, F. W., and Leonard, J. J.: Myocardial

Metabolism in Cyanotic Congenital Heart Disease 193

Schlosser, V.: see Blümchen, G.

Shaver, J. A.: see Scheuer, J.

Sideris, D. A. and Stamatelopoulos, S. F.: Correlation Between Atrial Fibril

lation and Some Hemodynamï Factors in Mitral Stenosis 361

Sievers, J.; Areskog, N.-H., and Stenport, G.: Right Atrial Myxoma with

Severe Cyanosis 55

Siripala, K. A.: see Nagaratnam, N.

Smith, C, jr.: see Levine, H. D.

Somers, K.: see Amorym, D. S.

Stabilyni, R.; Fiorelli, G.; Radice, F.; Marinari, M., and Agostoni, A.:

Lactate Dehydrogenase and Aspartate Aminotransferase Isoenzymes

in Normal and Hypertrophic Human Heart 28

Stamatelopoulos, S. F.: see Sideris, D. A.

Stenport, G.: see Sievers, J. 
Sulakhe, P. V.: see Dhalla, N. S.

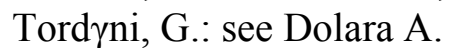

Torresani, J.; Chevalier-Cholat, Am.; Heupllet, G.; Fondarai, J. A.;

Saadjian, A., and Jouve, A.: Cardiac Response to Carotid Sinus

Nerve Stimulation in the Rabbit

94

VIII

Contents

Uyeyama, R. R.: see Aronow, W. S.

Vandermoten, P.: see Olsson, B.

Varnauskas, E.: see Olsson, B.

Vérel, D. and Chandrasekhar, K. P.: Congenital Complete Heart Block in Siblings 242

Wassén, R.: see Olsson, B.

Book Reviews

$63,128,255,371$

Varia 64,192, 372

Editorial

1

Subject Index Vol. 55374 